\title{
Litter Fall, Leaf Litter Decomposition, Soil Microfungi and Nutrient Content in Cocoa and Food Crop Agroforest Farmlands in Southeastern Ghana
}

\author{
Daniel Ako Tetteh \\ Department of Environmental Health and Sanitation Education, College of Agriculture, University of Skills Training and Entrepreneurial \\ Development, Kumasi, Ghana \\ Email address: \\ danieltet2003@yahoo.com

\section{To cite this article:} \\ Daniel Ako Tetteh. Litter Fall, Leaf Litter Decomposition, Soil Microfungi and Nutrient Content in Cocoa and Food Crop Agroforest \\ Farmlands in Southeastern Ghana. Ecology and Evolutionary Biology. Vol. 6, No. 3, 2021, pp. 92-98. doi: 10.11648/j.eeb.20210603.14
}

Received: May 9, 2021; Accepted: June 1, 2021; Published: August 2, 2021

\begin{abstract}
This study is a comparison of the litterfall, litter decomposition and soil microfungi species diversity in cocoa and mixed food crop agroforest farmlands. The study was carried out in the Atewa and Fanteakwa districts of the Eastern region of Ghana. A total of thirty six sampled plots size of five $25 \mathrm{~m} \mathrm{x} 25 \mathrm{~m}$ were randomly demarcated in cocoa agroforest, mixed food crop agrorest and the natural forest reserve. Data collected on litterfall mass and leaf litter decomposition at monthly intervals for a period five months. Soil microfungi species diversity was analyzed from soil samples collected at two depths $0-5 \mathrm{~cm}$ and $0-10 \mathrm{~cm}$ respectively using pour plate method. The reduction in mass of cocoa leaf litter was significantly negatively correlated with the number of days of decomposition. The rate of release of NPK was positively correlated with litter mass. Litter mass production significantly declined in the cocoa agroforest and mixed food crop agroforest farmlands. Initial rate of litter decomposition was generally slow in the cocoa and mixed food crop farmlands than in the natural forest. Soil microfungi species diversity was high in natural forest and low in the cocoa and mixed food crop agroforest farmlands.
\end{abstract}

Keywords: Litter Fall, Leaf Litter Decomposition, Microfungi, Cocoa Agroecosystems, Tropics

\section{Introduction}

Cocoa (Theobroma cacao $\mathrm{L}$ ) is one of the most important crop systems in tropical areas of South and Central America. Traditionally, the crop is grown under diversified native tree shade, increasingly viewed as a means of contributing to biodiversity conservation within agricultural landscapes [18] and complementing conservation in protected areas. It is evident that traditional cocoa plantations conserve birds, bats, insects and other wildlife to a greater extent than alternative land uses such as cocoa with little shade [18]. Unfortunately the cultivation of cocoa over the past decades has been associated with high levels of deforestation which has led to increase in secondary forest [28] and full sun cocoa production. According to [36], full-sun cocoa farming is currently the most widespread cocoa cultivation system in humid and subhumid regions of the world.
Litterfall and litter decomposition in agroforestry systems and subsequent nutrient release represent major biological pathways for soil nutrients transfer and play an important role in regulating nutrient cycling and in maintaining soil fertility in tropical agro-ecosystems [33]. Litter decomposition is a set of processes in which dead organic matter is converted into its components: carbon dioxide, mineral nutrients, and water. Knowledge of the decomposition of organic matter is of great importance in the management of areas under natural, agricultural, or silvicultural systems [31]. Most tropical soils are highly weathered, leached and nutrient poor [24], but the role of nutrients as factor determining decomposition process are largely unclear. Plant litter production and decomposition are the two important processes which provide the main input of organic matter in soil and regulate the patterns of 
nutrient cycling in forest ecosystems [10, 21, 26]. According to [2], the key process in nutrient recycling within ecosystems is decomposition, consisting of a series of physical and chemical processes by which leaf litter and foliage are reduced to their elemental chemical constituents. This is one of the most important events in ecosystems for their contribution of nutrients to the soil [1].

In the agroforestry systems, nutrients enter through various sources such as rain, fertilizers, and organic residues, and these can accumulate either in the shade trees, cultivation, soil, or litter. At the same time, interactions occur between crop layers such as residue deposition, infiltration, absorption, and mineralization; likewise, outputs can occur by crops yields, leaching, runoff, and denitrification processes. The study of the nutrient cycle in cocoa agroecosystems is fundamental to understand the dynamics of the elements and their availability in the sustainable management of the productive system.

Recent studies underlined the importance of microbiota for cycles of major elements and showed that global soil carbon projections could be improved by modelling microbial processes [20]. Fungi are the major decomposers of dead organic matter and contribute significantly in recycling of nutrients in natural and modified ecosystems [12]. Attempts have been made to review the underlying principle of fungal occurrence by studying the species composition of fungal communities during decomposition of various plant substrates [17]. High species diversity and spatial heterogeneity of decomposer fungi on decaying leaf litters in tropical forests have been reported [18]. These decomposer fungi play a vital role in maintaining the fertility and sustainability in the tropical forests [15].

In this study litterfall, litter decomposition and soil microfungi in mixed food crop agroforest and cocoa-based agroforest systems was investigated in order to make a comparison. This is useful information for farmers in the management of their farms and help as a decision support tool for farmers who decide to cultivate mixed food crops and cocoa-based agroforest system.

\section{Materials and Methods}

\subsection{Study Area}

The study was conducted in the Eastern Region of Ghana. Two sites were sampled intermittently during the study. The first site was the Atewa Range Forest Reserve in the Atewa District which represents the natural forest. The reserve is located between latitude $6^{\circ}$ and $6^{\circ} 10^{\prime} \mathrm{N}$ and longitude $0^{\circ}$ and $0^{\circ} 36^{\prime} \mathrm{W}$ and is about $232 \mathrm{~km}^{2}$ in size. Mean monthly temperature is between $24-29^{\circ} \mathrm{C}$ and the with the second occurring in September to November. The second site was at Adjeikrom in the Fanteakwa District where the traditional farming methods are practiced. The district lies within the equatorial region. Mean annual rainfall of the area accounts for about $1500 \mathrm{~mm}$ to $2000 \mathrm{~mm}$. The major season starts around March to April and ends at August to September. The minor season ends at October or first week of November. The mean annual temperature is between $26-27^{\circ} \mathrm{C}$. The vegetation in the Fanteakwa district is very typical of wet- semi deciduous forest, which covers about $80 \%$ of the total vegetation cover. Intense farming activities are therefore bringing about transition to this vegetation. Common tree species found in the area include Terminalia ivorensis A. Chev, Khaya ivorensis A. Chev, Triplochiton scleroxylon $K$. Schum, Cedrela odorata Blanco and Milicia excelsa Welw) C. C. Berg. Other food crops grown within the area are Musa sapientum L, Musa paradisica L., Prospe \& C. Jeffrey, Manihot esculenta Crantz, Zea mays L, Colocasia esculenta (L) Schott and Elaeis guineensis Jacq.

\subsection{Litter Mass Production}

The amount of litter mass production was monitored over a period of five months from November, 2008 to March, 2009 in the cocoa agroforest, mixed food crop agroforest and natural forest using litter trap of dimension $(1.0 \times 1.0 \times 0.2 \mathrm{~m}$ raised $50 \mathrm{~cm}$ ) above the ground. I randomly placed five (5) litter traps on five selected plots per land use. Thus a total fifteen (15) traps were used for the study. The position of the trap was constantly changed at every collection period to ensure the even distribution of litter. Litter intercepted by the traps was emptied monthly and sorted out into shaded tree leaf litter, cocoa leaf litter, flowers and twigs, and subsequently oven dried at $73.5^{\circ} \mathrm{C}$ until constant weight was achieved.

\subsection{Litter Decomposition}

To determine the rate of litter decomposition, cocoa leaf litter were collected and oven dried at $80^{\circ} \mathrm{C}$ for 24 hours. Ten grams $(10 \mathrm{~g})$ of the cocoa litter were weighed and evenly spread in each litter bag. For each land use type, five litter bags were arranged on the floor in order to undergo a period of decomposition. The litter bags were collected monthly from each land use type, oven dried and weighed. A portion of each decomposed litter was ground and sieved using a 0.5 $\mathrm{mm}$ sieve for the determination of nitrogen using the Kjeldahl method [8], available phosphorus following Bray1 method [7], exchangeable potassium determined using flame emission photometry (FEP) and organic carbon was determined by wet combustion method of [25].

\subsection{Soil Microbial Studies}

Soil microflora diversity was analyzed from soil samples collected at two depths, namely; $0-5 \mathrm{~cm}$ and $0-10 \mathrm{~cm}$. Two soil core samples were collected per $25 \mathrm{~m}$ x $25 \mathrm{~m}$ plot in October, 2008. Soil microflora was determined using the "Pour Plate" method [3] and the media was prepared using the modified Cooke's medium [9]. Species of soil microflora were identified and counted with the aid of mycologists from the Department of Botany, University of Ghana by consulting relevant literature [6]. 


\subsection{Statistical Analysis}

Statistical difference in the rate of litter mass among the different land-use types was analyzed using Analysis of Covariance (ANCOVA). The initial time $(\mathrm{t}=0)$ was removed from the analysis. Difference in mean total nitrogen, \% carbon, available phosphorus and exchangeable potassium in the three land-use types were analyzed using ANOVA and Tukey HSD test to compare means. The assumption of normality was assessed using the Shapiro-Wilk test [29]. The $\mathrm{R}$ software version 3.1.1 was used. The relationship between litter mass and number of days of decomposition was analyzed using Spearman correlation test. The rate of release of NPK was calculated as follows:

$$
\frac{A-B}{A} \times 100
$$

Where $\mathrm{A}=$ chemical content of non decomposed litter $\mathrm{B}=$ chemical content of decomposed litter

\section{Results}

\subsection{Litter Mass Studies}

The amount of different litter types produced over a period of 150 days in the three land-use types is presented in Table 1. Total mean litter produced was not significantly different (ANOVA, $p>0.05$ ) among the three land use types, but the amount of different litter types in most cases was significantly different among land-use types (ANOVA, $\mathrm{p}<$ 0.001 . Shade tree litter production was high throughout the period of the study. Cocoa litter produced was high between February and March.

The quantity of shade tree leaf litter produced was significantly (ANOVA, $\mathrm{p}<0.001$ ) different in the three land-use types. There were significant differences (Tukey HSD, $p>0.001)$ in the mean amount of shade tree leaf litter between the mixed food crops agroforest and the cocoa agroforest, and between the cocoa agroforest and natural forest (Tukey HSD, $\mathrm{p}>0.001$ ). Mean shade tree litter in the mixed food crops agroforest was twelve times higher than that found in the cocoa agroforest. However, there were no significant differences in the mean shade tree litter between the mixed food crops agroforest and the natural forest (Tukey HSD, $p=0.98$ ). The mean amount of shade tree flowers and twigs produced in the different land-use types was not significantly different $(p>0.05)$. Cocoa and food crops litter were only found in cocoa agroforest and mixed food crops agroforest, respectively. The mean amount of cocoa leaf litter produced was significant (ANOVA, $\mathrm{p}<0.01$ ). The quantity of cocoa flowers and twigs litter produced in the cocoa agroforest were, however, not significantly greater than zero (ANOVA, $p>0.05$ ). The mean amount of food crop leaves produced in the mixed food crops agroforestry was significant (ANOVA, $\mathrm{P}<0.05$ ).

Table 1. Summary of litter mass production statistics in the Cocoa Agroforest, Mixed Food crop Agroforest and Natural Forest in Southeastern Ghana.

\begin{tabular}{lllll}
\hline Litter type & $\begin{array}{l}\text { Natural forest } \\
(\mathbf{k g} / \mathbf{h a})\end{array}$ & $\begin{array}{l}\text { Cocoa agroforest } \\
\mathbf{( k g} / \mathbf{h a})\end{array}$ & $\begin{array}{l}\text { Mixed food crops } \\
\text { agroforest }(\mathbf{k g} / \mathbf{h a})\end{array}$ & $\begin{array}{l}\text { Statistical method of comparison of } \\
\text { means post hoc pair wise comparisons) }\end{array}$ \\
\hline Cocoa leaf & - & $27.19 \pm 3.53$ & - & ANOVA, $\mathrm{P}<0.001$ \\
Cocoa flower & - & $0.33 \pm 0.21$ & - & ANOVA, $\mathrm{P}=0.188$ \\
Cocoa twig & - & $0.43 \pm 0.22$ & - & ANOVA, $\mathrm{P}=0.298$ \\
Food crop leaf & - & - & $0.18 \pm 0.23$ & ANOVA, $\mathrm{P}=0.375$ \\
Shade tree leaf & $34.68 \pm 5.15$ & $3.46 \pm 0.95$ & $14.92 \pm 5.15$ & ANOVA, $\mathrm{P}<0.001$ \\
Shade tree flower & $0.34 \pm 0.14$ & - & $0.38 \pm 0.19$ & ANOVA, $\mathrm{P}=0.271$ \\
Shade tree twigs & $1.42 \pm 0.21$ & - & $0.44 \pm 0.21$ & ANOVA, $\mathrm{P}=0.286$ \\
Total annual litter & $36.44 \pm 5.5$ & $31.41 \pm 4.91$ & $15.92 \pm 5.78$ & \\
\hline
\end{tabular}

\subsection{Litter Decomposition}

The pattern of loss of dry matter during decomposition of cocoa leaf litter in the three land use types are shown in Figure 1. There was an initial rapid loss of litter mass followed by gradual reduction. The reduction in mass of cocoa leaf litter was significantly negatively correlated with the number of days of decomposition $(\mathrm{r}=-0.78, \mathrm{p}<0.001)$. After 151 days of decomposition the percentage cocoa leaf litter mass remaining was $65.4 \%, 68.6 \%$ and $70.4 \%$, respectively, for natural forest, mixed food crop agroforest and cocoa agroforest. There was a significant (ANCOVA, $p>$ 0.001 ) land use times number of days interaction in the decomposition of cocoa leaf litter mass.

The rate of release of NPK was positively correlated with litter mass loss $(r=, p<0.05)$. The initial mean amount of
NPK in the cocoa leaf litter before decomposition was $0.17 \pm$ $0.39 \%$ for nitrogen, $0.11 \pm 0.057 \mu \mathrm{g} / \mathrm{g}$ for phosphorous and $\left.5.02 \pm 2.24 \mathrm{~K}\left(\mathrm{cmol} /{ }^{+}\right)\right)$for potassium. After the 151 days of litter decomposition, about $44.9 \%$ of nitrogen was released in the natural forest, $43.7 \%$ in the mixed food crops agroforest and $42.1 \%$ in the cocoa agroforest (Figure 2). The rate of release of phosphorus was about $80.9 \%$ in the natural forest, $76.7 \%$ in the mixed food crops agroforest and $74.3 \%$ in the cocoa agroforest (Figure 1). The rate of release of potassium was about $69.1 \%$ in the cocoa agroforest, $67.7 \%$ in the natural forest and $64.9 \%$ in the mixed food crops agroforest (Figure 3). The trends of nutrient release from litter decomposition in the different land-use types showed a faster rate of released of potassium followed by phosphorus and the nitrogen. 


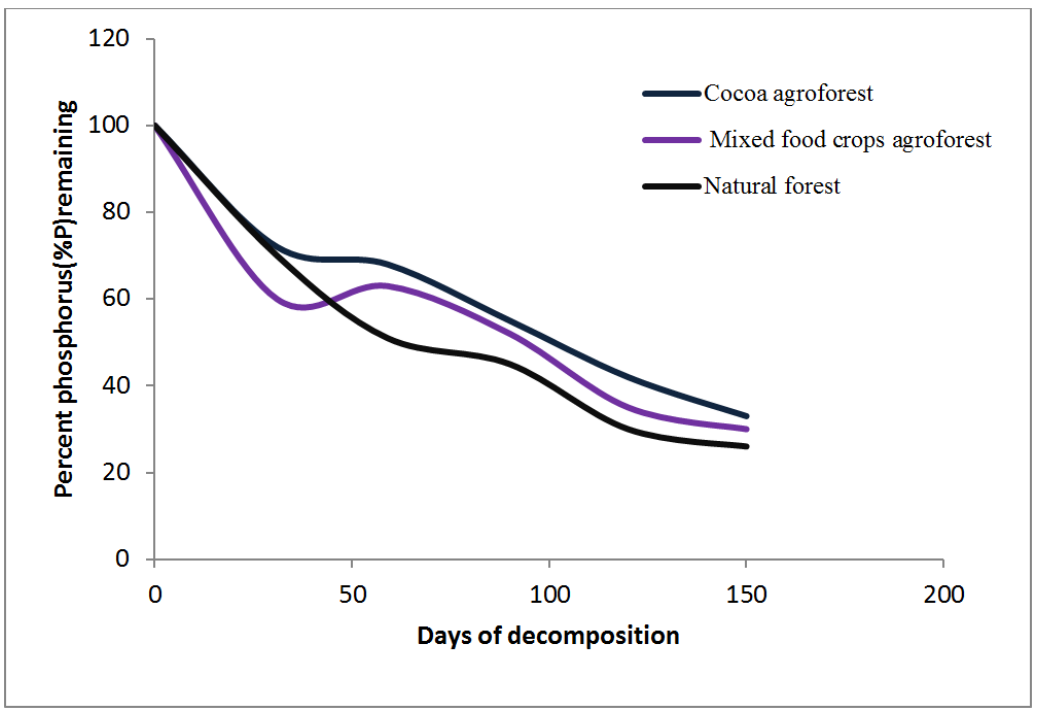

Figure 1. Rate of release of phosphorus from litter decomposition in the different Land use types.

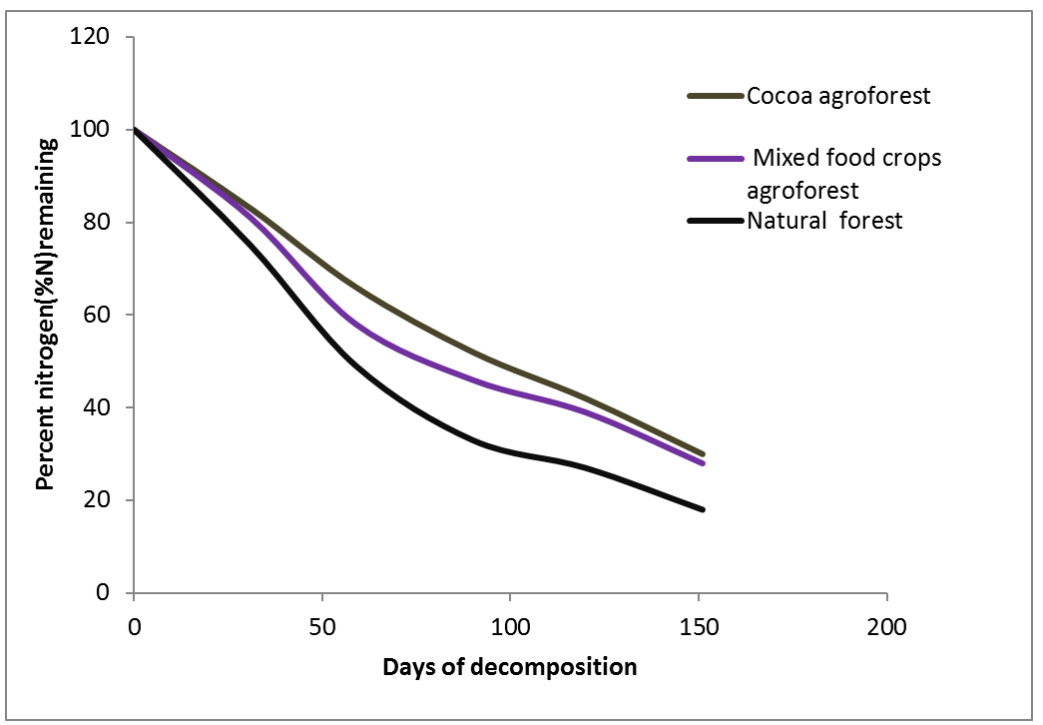

Figure 2. Rate of release of nitrogen from litter decomposition in the different Land use types.

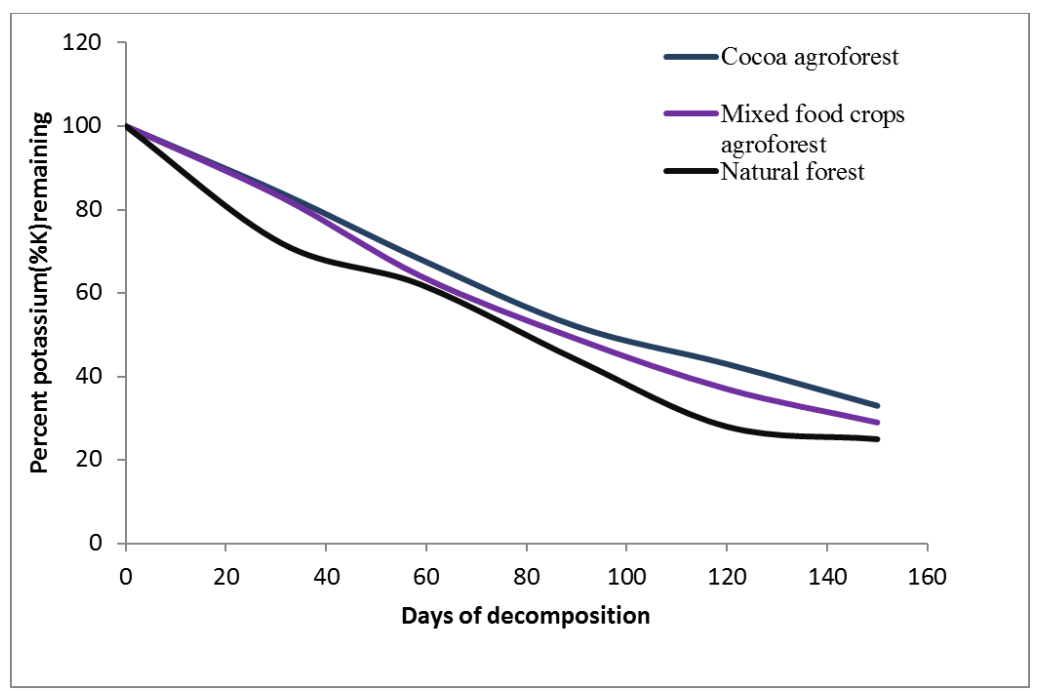

Figure 3. Rate of release of potassium from litter decomposition in the different Land use types. 


\subsection{Soil Microflora Diversity}

A total of 2892 individuals of soil microfungi belonging to 17 species in 8 families were identified (Table 2). Ten of these species, namely, Aspergillus flauvs, Aspergillus niger, Aspergillus giganteus, Aspergillus sulpherous, Cladosporium herbarium, Curvlaria lunata, Fusarium poae, Penicillium digitatum, Rhizopus oryzae and Rhizopus sterlonifer were found in all the three land use types. Members of the family Trichocomaceae was the most predominant in terms of number of species. About $36.1 \%$ of the species were found in the natural forest, $33.9 \%$ in the cocoa agroforest and 30.0\% in the mixed food crops agroforest. Thus soil microflora species richness was highest in the natural forest followed by the cocoa agroforest and then mixed food crops agroforest. The relative density of $58.8 \%$ of the species of soil microflora differed significantly $(p<0.05)$ among the three land-use types while that of $41.2 \%$ did not.

The population density of $41.2 \%$ of the species recorded was highest in the natural forest than in mixed food crops and cocoa agroforest. These species include Aspergillus flavus, Aspergillus niger, Cladosporium herbarium, Curvlaria lunata and Rhizopus oryzae and Rhizopus sterlonifer. The population density of $29.4 \%$ each was found to be higher in cocoa and mixed food crops agroforest.

Table 2. Diversity and relative abundance of soil microflora in the three land use types in an agroforestry landscape in southeastern Ghana.

\begin{tabular}{|c|c|c|c|c|}
\hline Species & Families & Natural forest & Mixed food crops agroforest & Cocoa agroforest \\
\hline Aspergillus alutaceus & Trichocomaceae & - & - & $0.17 \pm 0.1$ \\
\hline Aspergillus flavus Link & Trichocomaceae & $7.84 \pm 0.39$ & $6.17 \pm 0.46$ & $10.28 \pm 0.28$ \\
\hline Aspergillus giganteus & Trichocomaceae & $0.04 \pm 1.81$ & $0.22 \pm 1.19$ & $0.17 \pm 0.91$ \\
\hline Aspergillus niger Van Tieghem & Trichocomaceae & $5.28 \pm 0.36$ & $30.72 \pm 0.22$ & $30.39 \pm 0.16$ \\
\hline Aspergillus sulpherous & Trichocomaceae & - & $0.56 \pm 0.83$ & $0.83 \pm 0.52$ \\
\hline Blastomyces sp & Onygenaceae & - & $0.17 \pm 0.89$ & $0.72 \pm 0.99$ \\
\hline Cladosporium herbarium & Loculoascomycetes & $11.12 \pm 1.07$ & $1.72 \pm 1.16$ & $0.33 \pm 1.06$ \\
\hline Curvularia lunata Leakey & Loculoascomycetes & $11.48 \pm 0.71$ & $0.67 \pm 1.31$ & $1.89 \pm 0.67$ \\
\hline Fusarium poae & Hypocreaceae & - & $0.56 \pm 0.50$ & $0.67 \pm 0.68$ \\
\hline Fusarium solani & Hypocreaceae & $1.5 \pm 0.33$ & - & - \\
\hline Neurospora sitophila & Sordariaceae & $1.0 \pm 1.41$ & - & - \\
\hline Penicillium digitatum Currie \&Thom & Trichocomaceae & - & $1.17 \pm 0.57$ & $0.94 \pm 0.49$ \\
\hline Penicillium chryosogenum & Trichocomaceae & - & $0.28 \pm 0.89$ & - \\
\hline Rhizopus oryzae & Mucoraceae & $4.08 \pm 0.19$ & $2.89 \pm 0.23$ & $4.44 \pm 0.14$ \\
\hline
\end{tabular}

\section{Discussion}

\subsection{Litter Fall Studies}

Average total litterfall in this study was in the lower range of the values reported by the studies of $[27,28,35]$ in a similar study. The pattern of litter fall production showed a drastic reduction of shade litter in the mixed food crop agroforest and cocoa agroforest farmlands compared to that of the natural forest. The reduction of shade litter in could be attributed to high levels of deforestation which has led to increase in secondary forest leading to full sun cocoa production [36]. The reduction of shade trees in the cocoa and mixed food crop agroforest could greatly influence litter decomposition process and subsequently the release of nutrients into the plantation floor and uptake by the plants roots. Cocoa litter mass contributed to total litter mass recorded in the cocoa agroforest as observed in a previous study by [34]. Generally, the months of December and February recorded the highest litter mass and this can be due seasonal variations and climatic conditions as observed by [32]. The pattern of litterfall in this study was broadly comparable to other tropical ecosystems [21,23].

\subsection{Litter Decomposition Studies}

Initial litter mass loss in the different land use types gradually decreased during the period of decomposition, a pattern reported in other studies [5, 22, 34]. The rate of litter mass loss was faster in the natural forest compared to the cocoa and mixed food crop agroforest as reported by other authors $[28,35]$. The initial rapid loss is attributable to leaching associated with other factors such as microbial population, soil temperature and presence of moisture. Initial lost of litter mass occurred within the first 30-50 days in different land use types and remain unchanged throughout the period of decomposition. This observation agrees with report by $[5,14]$ who reported that $30-50 \%$ of leaf biomass decomposes in the first 3-4 months in tropical agroforestry and plantation systems. Generally, the release of nutrients in the different land use types showed a faster rate release of nitrogen and phosphorus compared potassium.

\subsection{Soil Microfungi Species Diversity}

In the present study, soil microfungal species diversity in forest soil was significantly higher than that found of mixed food crop and cocoa agroforest farmlands. The anthropogenic disturbances have been reported to reduce the diversity of fungal species under varied ecosystems [4, 22]. The rate of 
change in fungal population in the different land use types was attributed to vegetation type, variation in physicochemical characteristics of the soil and environmental complex of the locality [30]. This implies that soil ecological research over the past two decades has demonstrated extremely high levels of biological diversity belowground, especially in soil microfungi group [16]. The patterns of microbial populations in soils can also vary spatially and temporally according to factors such as the nature of the soil, parent material, availability of carbon resources, seasonal and diurnal variations in temperature, porosity and water holding capacity [16]. The diversity of soil microfungi is a requirement for the decomposition of litter essential for the release of organic compounds necessary for plant growth.

\section{Conclusion}

In conclusion, litter mass production significantly declined in the cocoa agroforest and mixed food crop agroforest farmlands. Initial rate of litter decomposition was generally slow in the cocoa and mixed food crop farmlands than in natural forest. Soil microfungi species diversity was high in natural forest than in the agroecosystems.

\section{Acknowledgements}

I express my profound gratitude to the cocoa farmers of Adjeikrom for their hospitality and support during the field data collection.

\section{References}

[1] Aber, D. and Melillo, J. M. (1991). Terrestrial Ecosystem. Saunders, College Publishing of Holt, Rinehart and Winston Orlando Florida.

[2] Aerts R. (1997). Climate, leaf litter chemistry and leaf litter decomposition in terrestrial ecosystems: A triangular relationship. Oikos 79, 439-449.

[3] Alexopoulos, C. J. and Beneke, E. S. (1962). Laboratory manual for introductory mycology. Burgess publishing $\mathrm{Co}$, Minneapolis.

[4] Allison, S. D, Hanson, C. A, Treseder, K. K. (2007). Nitrogen fertilization reduces diversity and alters community structure of active fungi in boreal ecosystems. Soil Biol. Biochem., 39: 1878-1887.

[5] Asigbaase, M., Dawoe, E., Sjogersten, S., \&Lomax B. L. (2020). Decomposition and nutrient mineralization of leaf litter in smallholder cocoa agroforests: a comparison of organic and conventional farms in Ghana. Journal of soils and sediments.

[6] Barnett, H. L. (1972). Illustrated genera of imperfect fungi. Burgess Publishing Co, Minnepollis.

[7] Bray R. H and L. T. Kurtz 1945. Determination of total organic and available forms of phosphorus in soils. Soil Sci. 59: $39-45$.

[8] Bremner, J. M. (1965). Total nitrogen. In: Methods of Soil
Analysis part 2. Chemical and microbiological properties. (eds) C. A. Black. Agronomy monograph 9. pp 1149-1178.

[9] Cooke, W. B, 1954. The use of antibiotics in media for the isolation of fungi from polluted water. Antibiot and chemother. Pp 4: 657-662.

[10] Facelli, J. M., Pickett, S. T. A., 1991. Plant litter: its dynamics and effects on plant community structure. Bot. Rev. 57, 1-32.

[11] Faria, D. R., Laps R, Baumgarten, J. and Cetra, M., 2006. Bat and bird assemblages from forests and shade cacao plantations in two contrasting landscapes in the Atlantic Forest of southern Bahia, Brazil. Biodiversity and Conservation 15: 587-612.

[12] Gadd, G. M., (2004). Mycotransformation of organic and inorganic substrates. Mycologist, 18: 60-70.

[13] Harvey, C. A., Gonza'lez, J. and Somarriba, E. 2006. Dung beetle and mammal diversity in forests, indigenous agroforestry systems and plantain monocultures in Talamanca, Costa Rica. Biodivers Conserv 15: 555-585.

[14] Kumar, B. M. (2008) Litter dynamics in plantation and agroforestry systems of the tropics - a review of observations and methods. In: Batish DR, Kohli RK, Jose S, Singh HP (eds) Ecological basis of agroforestry, 1st edn. CRC press, Boca Raton.

[15] Lodge, D. J. (1997). Factors related to diversity of decomposer fungi in tropical forests. Biodivers. Conserv., 6: 681-688.

[16] Nagendran, A. N., Deivendran, N. S. \& Prabvthi, S. (2014). Diversity of soil microbes under different Ecosystem land use patterns. Journal of Applied and Environmental Microbiology, 2: 90-96.

[17] Osono, T. (2006). Role of phyllosphere fungi on forest trees in the development of decomposer fungal communities and decomposition process of leaf litter. Can. J. Microbiol., 52: 701-716.

[18] Bossio, D. A., Scow, K. M. Gunapala, N. and Graham K. J. (1998). Determinants of soil microbial communities: Effects of agricultural management, season, and soil type on phospholipid fatty acid profiles. Microb. Ecol. 36: 1-12.

[19] Santana ME, Lodge DJ, Lebow P (2005). Relationship of host recurrence in fungi to rates of tropical leaf decomposition. Pedobiologia, 49: 549-564.

[20] Schroth, G., Fonseca da, G. A. B., Harvey, C. A., Gascon, C., Vasconcelos, H. L., Izac, A. M. N., (2004). Agroforestry and Biodiversity Conservation in Tropical Landscapes. Island Press, Washington.

[21] Sharma, G. D., Mishra, R. R \& Kshattriya, S. (1995). Fungi and litter decomposition in the tropics. In: Reddy MV (ed) Soil Organisms and Litter decomposition in the tropics. Westview Press, Boulder, pp. 39- 57.

[22] Singh, K. P., Singh, P. K., Tripathi, S. K. (1999). Litterfall, litter decomposition and nutrient release patterns in four native tree species raised on coal mine spoil at Singrauli. India. Biol. Fertil. Soils 29, 371-378.

[23] Tetteh, D. A. (2009). Agroforestry, ecosystem, biodiversity conservation: A case study in the Eastern Region of Ghana. Unpublished Mphil Thesis Dissertation. 
[24] Tripathi, S. K., Singh, K. P. (1995). Litter dynamics of recently harvested and mature bamboo savannas in a dry tropical region in India. J. Trop. Ecol. 11, 403-417.

[25] Vitousek, P. M., Sanford Jr., R. L., (1986). Nutrient cycling in moist tropical forest. Ann. Rev. Ecol. Syst. 17, 137-167.

[26] Walkley, A., Black, I. A., (1934). An examination of the method for determining soil organic matter, and a proposed modification of the chromic acid titration method. Soil Science, 34, 29-38.

[27] Weltzin, J. F., Keller, J. K., Bridgham, S. D., Paster, J., Allen, B. P., Chen, J., 2005. Litter controls plant community composition in a northern fen. Oikos 110, 537-546.

[28] Augusto, L. Ranger, J. Ponette, Q. and Rapp, M. (2002). Relationships between forest tree species, stand production and stand nutrient amount quantifying the difference between concentration values from the literature and actuals. Ann For Sci 57: 313-32.

[29] Barlow, J. Gardner, T. A, Ferreira, L. V., and Peres, C. A. (2007). Litterfall and decomposition in primary, secondary and plantation forests in the Brazilian Amazon. For Ecol Manage 247: 91-97.

[30] Crawley, M. J. 2007. The R book. Wiley, New York 942 p.

[31] Cardona, C. D. A, and Sadeghian, K. H. S. (2005). Cycle of nutrients and microbial activity in coffee plantations to free solar exposition and with shade of Inga spp. Cenicafé 56: 127141

[32] Cleveland, C. C., Townsend, A. R., Taylor, P., Alvarez- Clare, S., Bustamante, M. M., Chuyong, G., Dobrowski, S. Z., Grierson, P., Harms, K. E., Houlton, B. Z., Marklein, A., Parton, W., Porder, S., Reed, S. C., Sierra, C. A., Silver, W. L., Tanner, E. V. y Wieder, W. R. (2011). Relationships among net primary productivity, nutrients and climate in tropical rain forest: a pan-tropical analysis. Ecology letters, 14, 939-947.

[33] Luedeling, E., Smethurst, P. J., Baudron, F., Bayala, J., Huth, N. I., Noordwijk, M. V., Ong, C. K., Muha, R., Luciana, B., Muthum, C. y Sinclair, F. (2016). Field-scale modeling of tree-crop interactions: Challenges and development needs. Agricultural System, 142, 51-69.

[34] Ofori-Frimpong, K., Afrifa, A. A., Acquaye, A., (2010). Impact of shade and cocoa plant densities on soil organic carbon sequestration rates in a cocoa growing soil of Ghana. Afric. J. Environ. Sci. Technol. 4 (9), 621-624.

[35] Tetteh, D. A., Asase, A., Ofor-Frimpong, K., and Attuquayefio, D. (2018). Effect of cocoa farming intensification on biodiversity and ecosystem properties in Southern Ghana. Journal of Ecology and the Natural Environment.

[36] Tondoh, J. E., Kouame, F. N, Guei, A. M. G., Sey, B., Kone, A. W and Guessougou, N. (2015). Ecological changes induced by full-sun cocoa farming in Cote d'Ivoire. Global Ecology and Conservation pp 1-21. 